Int. J. Electrochem. Sci., 11 (2016) 3415 - 3424

\title{
Determination of the Stoichiometry, Stability Constant of Complexes Formation and Thermodynamic Parameters between 15-Crown-5, 1, 4, 8, 11-Tetrathiacyclotetradecane and 1, 7-Diaza-12-crown-4 Macrocyclic Ligands in Acetonitrile - Methanol Binary Solvent Mixtures
}

\author{
Malihe Samdi Kazemi ${ }^{1, *}$, Bita Shamshirgaran ${ }^{2}$ \\ ${ }^{1}$ Department of Chemistry, Faculty of Sciences, Bojnourd Branch, Islamic Azad University, Bojnourd- \\ Iran. \\ ${ }^{2}$ Department of Chemistry, Faculty of Sciences, Quchan Branch, Islamic Azad university, Quchan- \\ Iran. \\ *E-mail: samadi24243@yahoo.com
}

doi: $10.20964 / 110310$

Received: 22 December 2015 / Accepted: 14 February 2016 / Published: 1 April 2016

The complex formation between $\mathrm{Pb}^{2+}$ and $\mathrm{Ag}^{+}$metal cations with 15-crown-5 (15C5), 1, 4, 8, 11tetrathiacyclotetradecane (TTCTD) and 1, 7-diaza-12-crown-4 (DA12C4) macrocyclic ligands was studied in AN (acetonitrile) - $\mathrm{MeOH}$ (methanol) binary solvent mixtures using conductometric method. The stability constant of complexes obtained from fitting of molar conductivity data using GENPLOT computer program, also in all cases, the stoichiometry of the complexes was obtained 1: 1 $[\mathrm{M}: \mathrm{L}]$. The $\mathrm{Pb}^{2+}$ cation formed a more stable complex with $15 \mathrm{C} 5$ in $\mathrm{AN}-\mathrm{MeOH}(\mathrm{mol} \% \mathrm{AN}=75$ and 50) binary solvent mixtures than $\mathrm{Ag}^{+}$cation and the $\log \mathrm{K}_{\mathrm{f}}$ of (TTCTD.Ag) ${ }^{+}$complex derived bigger than (TTCTD.Pb) ${ }^{2+}$ complex. A non-linear behavior was observed between the $\log K_{\mathrm{f}}$ of the complexes versus the composition of a component of solvent in $\mathrm{AN}-\mathrm{MeOH}$ mixtures. The values of standard enthalpy changes $\left(\Delta H^{\circ} \mathrm{c}\right)$ for complexation reactions were obtained from the slope of the van't Hoff plots. The obtained results show that in most cases, the complexes are enthalpy destabilized but entropy stabilized and the positive values of entropy compensates of complex formation enthalpy.

Keywords: 15 -crown-5, 1, 4, 8, 11-tetrathiacyclotetradecane, 1, 7-diaza-12-crown-4, $\mathrm{Pb}^{2+}$ and $\mathrm{Ag}^{+}$ metal cations, Conductometry, Genplot.

FULL TEXT 
(C) 2016 The Authors. Published by ESG (www.electrochemsci.org). This article is an open access article distributed under the terms and conditions of the Creative Commons Attribution license (http://creativecommons.org/licenses/by/4.0/). 